\title{
Sero-Prevalence Study of Bovine Brucellosis in Lemu Bilbilo District of Oromia Regional State
}

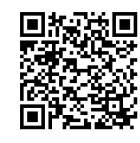

\author{
Tesfaye Belachew* \\ Assela Regional Laboratory, Animal Health Diagnostic, Ethiopia
}

Submission: July 17, 2018; Published: August 01, 2018

*Corresponding author: Tesfaye Belachew, Assela Regional Laboratory, Animal Health Diagnostic, Oromia, Ethiopia, Tel: +251933864966;

Email: teyobeku@gmail.com

\begin{abstract}
A cross sectional sero-prevalence study was carried out in Bokoji Town during March 2014 in order to determine the prevalence of bovine brucellosis. A standard questionnaire format was used to collect information relevant to the epidemiological investigation such as species, age and sex. The study subjects included 384 cross bred cattle reared under intensive management system. Blood samples were collected from animals above six months of age. The study animals were selected using simple random sampling method. A total of 411 blood samples were collected from jugular vein of each selected animal after proper restraining. The individual animals in the study were identified by their respective identification numbers or names. About $5-10 \mathrm{ml}$ of blood was collected in plain vacutainer tubes. The blood samples will be allowed to clot at room temperature. Serum was separated from clotted blood by decanting to cryogenic vial and was kept in a deep freezer $\left(-20^{\circ} \mathrm{C}\right)$ till tested serologically using the Rose Bengal Plate Test. The collected sera were tested by (RBPT) Rose Bengal Plate agglutination Test in Asella Regional Veterinary Laboratory and the sero-prevalence of bovine brucellosis in these areas was found to be $0 \%$. We appreciate the practices of the farms on the control of bovine brucellosis infection in this district. However, the following general sanitary measures are of some beneficial effect in preventing and controlling this disease for the future: Newly purchased animals must be isolated and tested for brucellosis before introducing them to the herd, contact during grazing with animals of unknown status must be avoided and Brucellosis test of all animals should be done at least once in a year.
\end{abstract}

Keywords: Bovine Brucellosis; Cattle; Goats; Camels; Equines; Bacteria; Swine; Undulant fever; Fixation Test; Infertility; Mammals; Hygromas; Reproductive; Orchitis; Livestock

\section{Introduction}

Brucellosis is a contagious disease of livestock with significant economic impact. The disease is caused by various bacteria of the family Brucella, which tend to infect a specific animal species. However, most species of Brucella are able to infect other animal species as well. It affects cattle, swine, sheep and goats, camels, equines, and dogs. It may also infect other ruminants, some marine mammals and humans [1]. The appearance of brucellosis depends on the Brucella species being prevalent in other animals sharing their habitat (cross transmission between species) and on the husbandry system.

The disease in animals is characterized by abortions or reproductive failure. While animals typically recover and will be able to have live offspring following the initial abortion, they may continue to shed the bacteria. Brucellosis in cattle (B. abortus) in sheep and goats (B. melitensis) and in swine (B. suis) are diseases listed in the World Organization for Animal Health [2]. Adult male cattle may develop orchitis and brucellosis may be a cause of infertility in both sexes. Hygromas, usually involving leg joints, are a common manifestation of brucellosis in some tropical countries and may be the only obvious indicator of infection; the hygroma fluid is often infected with Brucella. (OIE May 2009). Free grazing and movement with frequent mixing of flocks of sheep and goats also contribute to the high prevalence and wide distribution of brucellosis [3].

B. abortus is found worldwide in cattle-raising regions, except in Japan, Canada, some European countries, Australia, New Zealand and Israel, where it has been eradicated. Eradication from domesticated herds is nearly complete in the U.S. B. abortus can be found in wildlife hosts in some regions, including the Greater Yellowstone Area of North America [4]. Although brucellosis has been, or is close to being, eradicated from a number of developed countries, it continues to be a major public and animal health problem in many regions of the world, particularly where livestock are a major source of food and income. There are many reasons why brucellosis remains endemic. These include expansion of livestock herds and flocks, with associated uncontrolled movements; lack of veterinary 
support services and vaccines; and husbandry practices favoring the spread of infection. Human cases continue to occur following international travel, traditional use of raw milk products and following close contact with infected animals [5].

Initial infection in the reservoir species is often followed by abortion and subsequent delayed or permanent infertility. Infection is usually chronic in animals, and treatment is rarely undertaken. Infected animals shed the organisms in uterine discharges following abortion and subsequent parturition, and also in the colostrums and milk. Brucellosis is a herd or flock problem. It is spread within the herd primarily by ingestion of contaminated material. Venereal infections can also occur, but this is mainly seen with B. suis infections. Congenital (in utero) or perinatal infections may also occur, with the ensuing development of latent infections. Spread between herds usually occurs by the introduction of asymptomatic chronically-infected animals [5]. In dairy production, the disease is a major obstacle to the importation of high yielding breeds and represents a significant constraint to the improvement of milk production through crossbreeding [6].

The World Health Organization (WHO) laboratory biosafety manual classifies brucella in Risk group III. Brucellosis is readily transmissible to humans, causing acute febrile illness - undulant fever - which may progress to a more chronic form and can also produce serious complications affecting the musculo-skeletal, cardiovascular, and central nervous systems. Precautions should be taken to prevent human infection. Infection is often due to occupational exposure and is essentially acquired by the oral, respiratory, or conjunctival routes, but ingestion of dairy products constitutes the main risk to the general public where the disease is endemic. There is an occupational risk to veterinarians and farmers who handle infected animals and aborted fetuses or placentas. Brucellosis is one of the most easily acquired laboratory infections, and strict safety precautions should be observed when handling cultures and heavily infected samples, such as products of abortion [1].

Brucellosis is perhaps one of the most widespread and economically important diseases in tropical and subtropical regions. The direct loss of meat (because of abortion, infertility and weight loss) in infected herds of cattle was estimated to be $15 \%$ and for milk (reduction in milk production) $20 \%$ per infected cow Nicoletti et al. \& Staak $[7,8]$. Describing the current sero-prevalence of bovine brucellosis in cattle with intensive management system in Bokoji Town of Arsi Zone, Oromia Regional State, Ethiopia.

\section{Materials and Methods}

\section{Study area}

The study was conducted in Bokoji Town of Lemu Bilbilo district of Oromia National Regional State. The town is located at a geographic coordinate of 07032 'North latitudes and. 0390 $15^{\prime}$ East longitudes. The city is found at $205 \mathrm{~km}$ away from to the south eastern parts of the country at an elevation of 2817 meter above sea level. It receives biannual rainfalls with the average temperature ranges from 6 to $19{ }^{\circ} \mathrm{C}$ [9-11]. In this area mixed crop and livestock farming system was practiced.

\section{Study Animal and Study Design}

A cross sectional sero-epidemiological study was carried out in Bokoji Town during March 2014. A standard questionnaire format was used to collect information relevant to the epidemiological investigation such as species, age and sex. The study subjects included cross bred cattle reared under intensive management system. Blood samples were collected from animals above six months of age $[12,13]$. The study animals were selected using simple random sampling method. A total of 384 blood samples were collected from jugular vein of each selected animal after proper restraining. The individual animals in the study were identified by their respective identification numbers or names. About $5-10 \mathrm{ml}$ of blood was collected in plain vacutainer tubes. The blood samples will be allowed to clot at room temperature. Serum was separated from clotted blood by decanting to cryogenic vial and was kept in a deep freezer $(-20$ ${ }^{\circ} \mathrm{C}$ ) till tested serologically using the Rose Bengal Plate Test. Sera testing positive, were tested further by Complement Fixation Test (CFT) OIE [1]. The data collected were stored in Microsoft Excel spreadsheet and was analyzed using descriptive statistics

\section{Results and Recommendations}

The sero-prevalence of bovine brucellosis in the study area was found to be $0 \%$. The practices of the farms on the control and prevention of bovine brucellosis infection is highly appreciated. However, the following general sanitary measures are of some beneficial effect in controlling and preventing this disease for the future: Newly purchased animals must be isolated and tested for brucellosis before introducing them to the herd, contact during grazing with animals of unknown status must be avoided and in case of uncertainty bovine brucellosis test of all animals should be done immediately at least once in a year.

\section{References}

1. OIE (2009) OIE (World Organisation for Animal Health) (2009) Bovine brucellosis, In Manual of Standards for Diagnostic Tests and Vaccines. OIE, Paris p. 1-35.

2. OIE (2010) Terrestrial Animal Health Code Brucellosis.

3. Tanmay J Patel (2007) serological cultural and molecular detection of brucela infection in bovines including quantification in milk by real time PCR. master Thesis, Anhand Agricultural University, Gujarat, India.

4. IVIS.org (2007) Bovinr brucellosis.

5. FAO (2003) Guidelines for coordinated Human and Animal brucellosis Surveillance. Animal Production and Health paper pp. 156.

6. Mustefa M, Nicoletti P (1993) FAO, WHO, OIE guidelines for regional brucellosis control programme for the Middle East. Prepared at a workshop held in Amman, Jordan p. 14-17.

7. Nicoletti P (1980) The epidemiology of bovine brucellosis. In: Brandly CA, Corneleius GA (Eds.), Advance in Vet. Sci. Comparative Med. New York Academic Press, Newyork, USA, 24: 68-69. 
8. Staak C (1990) Serological techniques in brucellosis and interpretation of results. First Int. Conf. on brucellosis, Iraq.

9. Animal Disease Factsheets (2007) IVIS Org, The Center for Food Security \& Public Health. Iowa State University, Ames, IA, USA.

10. Deselegn and Gangwar (2011) Seroprevalence study of bovine brucellosis in assela government dairy farm of oromia regional state. Ethiopia 2(3): 692-697

11. Ibrahim N, Kelay B, Lobago F, Bekana M (2010) Sero-prevalence of Bovine brucellosis and its risk factors in Jimma zone of Oromia Region,
South-westrn Ethiopia. Tropical Animal Health and Production 42: 3540.

12. Teshale S, Aschalew Z, Gelagay A, Basu AK (2006) Preliminary study on prevalence of Brucella antibodies in sheep and goats in Borana Southern Ethiopia. J Nat Hist 2: 710

13. Thrusfield M (2007) Veterinary Epidemiology. ( $3^{\text {rd }}$ edn), Black well science Ltd. United Kingdom, pp. 182-198.

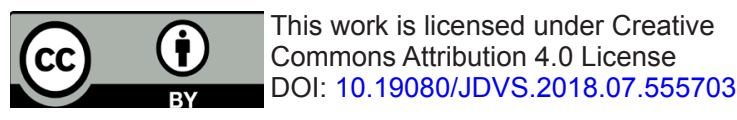

\author{
Your next submission with Juniper Publishers \\ will reach you the below assets \\ - Quality Editorial service \\ - Swift Peer Review \\ - Reprints availability \\ - E-prints Service \\ - Manuscript Podcast for convenient understanding \\ - Global attainment for your research \\ - Manuscript accessibility in different formats \\ ( Pdf, E-pub, Full Text, Audio) \\ - Unceasing customer service \\ Track the below URL for one-step submission \\ https://juniperpublishers.com/online-submission.php
}

